\title{
IMAGINING A COUNTERFACTUAL SECTION 36: REBALANCING NEW ZEALAND'S COMPETITION LAW FRAMEWORK
}

\author{
Andrew I Gavil
}

\begin{abstract}
Like the competition-related laws of most other nations, s 36 of New Zealand's Commerce Act 1986 includes a prohibition of some unilateral acts by firms with substantial market power. Such prohibitions reflect the consensus view of many jurisdictions, courts and commentators that the anticompetitive potential of unilateral conduct largely depends on the market power of the firm undertaking it. In lieu of an inquiry into the actual or probable effects of challenged conduct, however, 36 has been interpreted to rely on a "counterfactual" test, seemingly unique in the world. Under that approach, courts have been directed to ask whether a firm lacking substantial market power would have engaged in the same conduct, and from the answer to that question to infer the likely effects of the conduct by the firm with market power. This article argues that the counterfactual test will frequently be an unreliable method for implementing the language and underlying purposes of $s$ 36. In many common circumstances it will likely fail to proscribe conduct that may well be harmful to competition and consumers, and result in systematic under-deterrence. In other cases, it may fail to recognise and credit efficiencies that might be unique to the firm with market power, and hence over-deter procompetitive conduct. The article concludes by considering several options for reform.
\end{abstract}

* Professor of Law, Howard University School of Law, Washington DC. This article is adapted from remarks delivered at the New Zealand Commerce Commission's inaugural Competition Matters conference, 17-18 October 2013. At that time, the author was serving as Director, Office of Policy Planning, United States Federal Trade Commission. The views expressed, however, are personal and should not be interpreted as the views of the United States Federal Trade Commission or any of its Commissioners. The author would like to thank Patricia Schultheiss and Cynthia L Lagdameo for their contributions and comments, and Marcus J Bandy for his research and editing assistance. The author would also like to express his deep appreciation to Professor Paul Scott, David Blacktop, Richard Sanders and Lilla Csorgo for their encouragement and many helpful suggestions. Finally, the author expresses his gratitude to Dr Mark Berry, Chairman of the New Zealand Commerce Commission, for his gracious invitation to participate in the agency's inaugural conference. 
"Where a defendant maintains substantial market power, his activities are examined through a special lens: Behavior that might otherwise not be of concern to the antitrust laws - or that might even be viewed as procompetitive_can take on exclusionary connotations when practiced by a monopolist." 1

\section{INTRODUCTION}

Justice Antonin Scalia's dissenting opinion in Eastman Kodak Co v Image Technical Services, Inc, quoted above, expresses a proposition that is widely accepted by economists and most competition enforcement regimes around the world: the anticompetitive potential of unilateral conduct largely depends on the market power of the firm undertaking it. ${ }^{2}$ It is also implicit in the competition statutes of every jurisdiction that has prohibited anticompetitive unilateral conduct. The examination of unilateral conduct, therefore, begins with an inquiry into the power of the firm. It then logically moves on to consider the nature and competitive effects of the conduct under examination. Whether evaluating past conduct or undertaking prospective analysis of current or proposed conduct, the paramount goal is to evaluate the conduct's actual or probable competitive effect. $^{3}$

1 Eastman Kodak Co v Image Technical Services Inc 504 US 451 (1992) at 488 per Justice Scalia dissenting. In support of this proposition, Justice Scalia cited the then current edition of the authoritative Areeda and Turner treatise on antitrust law. The equivalent point is made in the current edition: "The definition of 'exclusionary conduct' [in this treatise] ... was predicated on the existence of substantial market power. Those definitions cannot be automatically carried over to firms without such power. A given act might be significantly anticompetitive only when the actor possesses substantial power." Phillip E Areeda and Herbert Hovenkamp Antitrust Law (3rd ed, Aspen Publishers, New York, 2008) vol 3B at 394. Similarly, the treatise authors note at 423 that "conduct that would have significant anticompetitive effects when coupled with substantial market power may well have negligible or no effect when power is slight or nonexistent. In that event, the conduct would not be harmful and would not contribute significantly to any market power that the actor might have or eventually obtain." See also United States $v$ Dentsply International Inc 399 F 3d 181 (3rd Cir 2005) at 187: "Behavior that otherwise might comply with antitrust law may be impermissibly exclusionary when practiced by a monopolist."

2 It was urged upon the New Zealand Supreme Court by the New Zealand Commerce Commission in Commerce Commission v Telecom Corp of New Zealand Ltd [2010] NZSC 111, [2011] 1 NZLR 577 [0867]; noted in Melway Publishing Pty Ltd v Robert Hicks Pty Ltd [2001] HCA 13, (2001) 205 CLR 1; and cited by several commentators. See for example, Paul G Scott "Taking a Wrong Turn? The Supreme Court and Section 36 of the Commerce Act" (2011) 17 NZBLQ 260 at 264, 268 and 275; and Rex T Ahdar "The unfulfilled promise of New Zealand's monopolisation law: Sources, symptoms and solutions" (2009) 16 CCLJ 291 at 294. New Zealand Commerce Commission Chairman, Dr Mark Berry, has made the same observation: "It is not difficult to identify instances where unilateral conduct may be of no concern, or even pro-competitive, when undertaken by a non-dominant firm in a competitive market, but may well be anticompetitive and cause consumer harm when engaged in by a dominant firm." Mark N Berry "New Zealand Antitrust: Some Reflections on the First Twenty-Five Years" (2013) 10 Loy U Chi Int'l L Rev 125 at 145 .

3 Professor Steven C Salop has described this prioritisation of competitive effects as a "first principle" of modern competition law. See for example Steven C Salop "The First Principles Approach to Antitrust, Kodak, and Antitrust at the Millennium" (2000) 68 Antitrust LJ 187. As Salop explained at 188: "The first 
This focused inquiry into effects, both pro and anticompetitive, is not limited to single-firm conduct. It is a unifying principle that influences how competition law authorities and courts approach the analysis of most collaborative agreements, distribution arrangements and mergers. And virtually all prohibitions of single-firm conduct, including New Zealand's s 36, have a threshold requirement that the single firm possess some degree of market power, whether it is characterised as a "monopolist", a "dominant firm", or a firm possessing "substantial market power". Similarly, many enforcement guidelines reflect it, creating "safe harbours" for conduct undertaken by firms that are unlikely to possess or obtain market power. ${ }^{4}$ The complete integration of these two propositions into the fabric of modern competition policy - that competitive harm is the central concern of competition laws and that such harm is unlikely absent a degree of market power - can be understood as one of the most concrete achievements of advocates of a more "economic" approach to competition analysis.

Most jurisdictions have come to accept, therefore, that there are good reasons to more carefully scrutinise certain kinds of conduct when practised by a firm or a group of firms with market power. Although evidence that the practice is followed by firms who lack market power may suggest that there are legitimate business reasons for it, such as efficiencies, that evidence alone cannot substitute for an inquiry into the effects of the same conduct when practised by a dominant firm. To reach a judgment about the impact of the conduct on competition, it is necessary to evaluate it in a specific context giving due consideration to the particular characteristics of both that firm and the market and this is true for both potentially anti and procompetitive effects. It is widely accepted, for example, that exclusive dealing or other kinds of distribution arrangements can be procompetitive or of little competitive consequence when practised by firms lacking market power. These procompetitive possibilities do not vanish when the same conduct is practised by a firm with market power and hence they will be relevant to any assessment of that firm's conduct. But the conduct's potential anticompetitive effects can be quite different and, as Justice Scalia recognised, might warrant examination through a "special lens" when practised by a firm with market power, precisely because of the firm's power. ${ }^{5}$ The mere possibility of efficiencies, as evidenced by a practice's

principles approach centers on an examination of the competitive effects of the conduct at issue. This is appropriate because competitive effect is the true core of antitrust. Although market power and market definition have a role in antitrust analysis, their proper roles are as parts of and in reference to the primary evaluation of the alleged anticompetitive conduct and its likely market effects. They are not valued for their own sake, but rather for the roles they play in an evaluation of market effects." See also Andrew I Gavil "Moving beyond Caricature and Characterization: The Modern Rule of Reason in Practice" (2012) 85 S Cal L Rev 733 at $748-751$.

4 See for example European Commission Guidance on the Commission's enforcement priorities in applying Article 82 of the EC Treaty to abusive exclusionary conduct by dominant undertakings (February 2009) at [14] [EC Guidance on Abuse of Dominance]: "Dominance is not likely if the undertaking's market share is below $40 \%$ in the relevant market".

5 This "special lens" shares a common foundation with the "special responsibility" sometimes cited in European competition law. See for example EC Guidance on Abuse of Dominance, above at 4, at [1]; and 
adoption by non-dominant firms, should not obviate the necessity of an inquiry into its overall effects when practised by a dominant firm.

Finally, although the experience of other, non-dominant firms is relevant, it is generally not the predominant focus of the inquiry in most jurisdictions. Diverting attention from the dominant firm's conduct and its effects, both anti and procompetitive, to the non-dominant firms in an industry, can become a distraction and a poor use of the limited resources of agencies, parties and courts. Like a magician's trick, focusing the investigation and litigation of a case of dominant firm conduct on the potential efficiencies realised by other, non-dominant firms draws attention away from the proper focus of the inquiry: the dominant firm and the effects of its conduct.

These widely accepted principles of competition law and economics have been obscured by the New Zealand Supreme Court's adoption of the "counterfactual" test for judging whether a single firm's conduct violates the prohibitions of s 36. By focusing the analysis on whether a firm lacking substantial market power would have engaged in the same conduct, the counterfactual test substitutes a hypothetical inquiry into the conduct's possible efficiencies when practised by a nondominant firm for the more important question of its actual or probable effects, both pro and anticompetitive, when practised by a specific dominant firm in a market with observable characteristics. It trades an inquiry into actual or probable harms, efficiencies and motivations in a real world market for a hypothetical inquiry that reveals only whether some efficiency might justify the conduct by some other firm lacking market power. It does not pose the more relevant and illuminating efficiency-related question: whether the dominant firm's conduct had a significant anticompetitive effect, taking into account evidence of efficiencies, if any. Reliance on the counterfactual test, therefore, is very likely to produce "false negatives"; that is, it will fail to condemn conduct that warrants prohibition, precisely because it fails to attribute any significance to the dominant firm's market power. The test has also been criticised as being complex and difficult to apply, because the hypothetical market will be challenging to construct with any confidence. It will also be too dependent on hypothetical, as opposed to more relevant, real-world evidence and comparisons. ${ }^{6}$

Robert O'Donoghue and A Jorge Padilla The Law and Economics of Article 102 TFEU (2nd ed, Hart Publishing, Oxford, 2014) at 177. Both phrases serve to acknowledge that dominant firms may not be permitted to undertake the same conduct as non-dominant firms because the effects of that conduct may be different owing to their market power. The invocation of "responsibility", however, has had broader implications under European Union law and has arguably led to findings of infringement in a wider range of conduct, leading some commentators to observe that it can range beyond welfare-reducing conduct. See for example Pinar Akman The Concept of Abuse in EU Competition Law: Law and Economic Approaches (Hart Publishing, Oxford, 2015) at 59-60 and 63. See also Alison Jones and Brenda Sufrin EU Competition Law (5th ed, Oxford University Press, Oxford, 2014) at 374-375: "The principle that dominant firms have a 'special responsibility' towards the competitive process ... imposes what is in effect a positive, or affirmative, duty on the dominant undertaking to act in certain ways."

6 See for example Ahdar, above n 2, at 298 
Nevertheless, the counterfactual test has been defended on a number of grounds. First, it has been argued that the test is essential as a means to rationalise the language of s 36, which might otherwise permit condemnation of normal, albeit aggressive competition, undertaken for the purpose of harming rivals absent harm to competition. It can be easy to mistake such conduct for "anticompetitive" conduct and some test is required to differentiate hard competition from "exclusionary" or "abusive" non-merits-based competition, because both can result in market "winners" and "losers". Secondly, it has been argued that the counterfactual test provides a bright line - some needed certainty and predictability to dominant firms, especially when they act in response to new competitive challenges. Such firms might otherwise be inhibited from pursuing aggressive strategies for fear of investigation and a finding of liability. ${ }^{7}$ And finally, proponents of the test have argued that it will preserve the incentives necessary to promote long-term, dynamic efficiencies. ${ }^{8}$

More broadly, the counterfactual approach can be defended on a number of grounds typically associated with non-interventionist perspectives on competition law enforcement. The argument would go as follows: market solutions for competitive problems are preferable to governmentimposed ones; market power tends to be self-correcting because its exercise attracts entry and hence monopolies are not likely to be durable; enforcement agencies and especially courts are insufficiently schooled in complex economic analysis and hence their decisions will be prone to error given the complexity of market analysis; erroneous decisions will deter procompetitive conduct and may do so without correction for years to come; and the costs of administering complex rules outweigh the benefits of having standards that demand only relatively simple inquiries. Many of these arguments have been challenged ${ }^{9}$ and may be an especially poor fit for a relatively smaller, geographically isolated economy such as New Zealand's, where high levels of concentration already characterise many industries and entry is complicated by a variety of factors. They also do not appear to be a fair assessment of the strengths and weaknesses of the counterfactual test. Ironically, like the test itself, these arguments in its favour tend to substitute abstract theory and assumptions for more measurable reality.

In this article, I will argue that the counterfactual test is unlikely to provide an effective means to differentiate competitively harmful from beneficial conduct in many cases. To the contrary, it is very likely to lead to a significant incidence of erroneous conclusions, especially false negatives,

7 Often overlooked is that "certainty and predictability" are not concerns solely of large, established, incumbent firms. New entrants (and their investors) intent on challenging incumbent firms also need a degree of certainty that they will be free to compete on the merits and not subjected to strategic conduct by the incumbent.

8 See for example Matt Sumpter "Competition Law" [2012] NZ L Rev 113 at 126-130.

9 See Jonathan B Baker "Taking the Error Out of 'Error Cost' Analysis: What's Wrong with Antitrust's Right" (2015) 80 Antitrust LJ 1 
and likely under-deterrence. It will tend to insulate incumbent firms with substantial market power in highly concentrated industries from competitive challenges, perpetuate the current, concentrated market structure that is prevalent in a number of industries in New Zealand, and diminish, not promote, the long-term dynamism of the economy. The counterfactual also will be susceptible to producing false positives. In practice, because it focuses on the incentives of non-dominant firms, it will systematically fail to recognise and credit efficiencies that are uniquely available to the dominant firm. Such efficiencies may escape notice under the counterfactual approach, and result in condemnation of conduct that may be procompetitive or competitively neutral because they are not accessible by the non-dominant firm.

Finally, continued reliance on the counterfactual likely will have negative institutional consequences for the New Zealand Commerce Commission (NZCC) and the courts. First, it will impede the development of the law and economics of exclusion in New Zealand, causing it to fall behind developments in much of the rest of the world, perhaps for decades to come. The most advanced legal methods and economic techniques necessary to assess exclusion may not develop, or will develop more slowly, because they are not deemed relevant by the courts under the counterfactual. Even if the NZCC elects to follow globally recognised best practices in exercising its prosecutorial discretion, when it decides to initiate proceedings it will be forced by necessity to recast the case in anticipation of the court's application of the counterfactual. Doing so will necessarily drain its resources and likely give rise to an institutionally stressful discontinuity between the investigatory and adjudicative stages of its s 36 cases.

Part II of this article examines the test itself. Internally, the test can be questioned for relying on debatable inferences and presumptions, and for not undertaking any true "comparison" with the most important and available benchmark - the actual market in which the challenged conduct occurred. Moreover, in all but the simplest of circumstances, it will not provide certainty and predictability. It can be costly to implement and uncertain in its outcome. Finally, the test seems more likely to undermine, not promote, dynamic efficiencies, because it will tend to insulate dominant firms from competitive challenges from new products, services and business models, reducing their incentive to innovate and emboldening them to undertake conduct that may impede new entry. It will, therefore, deter firms from challenging dominant firms and discourage investment in new entrants by the financial community. As noted, it will also tend to undervalue efficiencies uniquely available to the dominant firm. As a way to summarise and focus these various arguments, Part II concludes by applying a decision-theoretic approach to the evaluation of the counterfactual, concluding that it fairs poorly when judged for its tendency toward significant error and high costs of administration.

Part III offers an alternative reading of s 36, one that considers it within the broader context of the Commerce Act 1986, rather than in isolation. Section 36 selectively borrows features from the Commerce Act's other provisions, yet as interpreted stands apart from them owing to reliance on its unique version of the counterfactual. The counterfactual thus has created an internally inconsistent 
and dissonant overall competition law framework. In lieu of the counterfactual, an effects-focused interpretation of its "taking advantage of" language could better align and harmonise s 36 with the Act's other competition-focused provisions. Similar methodologies would be applied to evaluate similar harms and benefits across its many provisions. Such an approach could help to promote a more integrated overall framework guided by a focused and common set of foundation principles.

Part IV turns to the international community and assesses the counterfactual test in the context of global norms for evaluating single-firm conduct. Although it appears that s 36 was supposed to follow Australia's lead, it has evolved to be less flexible. Whereas the New Zealand Supreme Court appears to have mandated exclusive reliance on the counterfactual to assess whether a firm has taken advantage of its market power, Australia's s 46 has been amended so that the counterfactual is explicitly but one approach to be considered. ${ }^{10}$ Australia also appears to be poised to undertake a broader evaluation and amendment of its entire competition law framework, although debate continues. $^{11}$

More broadly, and as is well understood in New Zealand, the counterfactual is an anomaly in the global competition policy community. It is unique and arguably inconsistent with global norms for evaluating single-firm conduct. In other jurisdictions, courts and enforcement agencies tend to focus on the effects of dominant firm conduct in both the assessment of market power and in judging "exclusionary" or "abusive" conduct. In using counterfactual analysis, other jurisdictions focus solely on the dominant firm and compare the performance of the relevant market with and without the dominant firm's challenged conduct. As far as I can tell, none rely on the behaviour of a hypothetical non-dominant firm as the basis for counterfactual analysis. To illustrate this point, Part

10 Amended in 2010, Australia's equivalent of s 36 now includes an express direction that the counterfactual is to be used as only one of several possible approaches (Competition and Consumer Act 2010 (Cth), s 46(6A)):

(6A) In determining for the purposes of this section whether, by engaging in conduct, a corporation has taken advantage of its substantial degree of power in a market, the court may have regard to any or all of the following:

(a) whether the conduct was materially facilitated by the corporation's substantial degree of power in the market;

(b) whether the corporation engaged in the conduct in reliance on its substantial degree of power in the market;

(c) whether it is likely that the corporation would have engaged in the conduct if it did not have a substantial degree of power in the market;

(d) whether the conduct is otherwise related to the corporation's substantial degree of power in the market.

This subsection does not limit the matters to which the court may have regard.

11 See Competition Policy Review Final Report (Australian Government, March 2015). 
IV will examine the experience of a sampling of other jurisdictions to demonstrate that conduct likely to be condemned elsewhere might well be permitted in New Zealand owing to s 36's unduly narrow current construction. It will highlight in particular some of the "abuse of dominance" guidelines issued by a number of jurisdictions and some well-known cases.

The article concludes by briefly considering several approaches to revising or eliminating the counterfactual test. First, it will examine an alternative formulation of the counterfactual test; one that reverses its focus from the hypothetical firm without market power to the dominant firm allegedly exercising its market power. Instead of asking whether a hypothetical firm without market power might also have had reason to adopt the conduct, it would ask whether the dominant firm's market power provided it with exclusionary benefits from the challenged conduct that would not likely have accrued to a firm without market power. In other words, to determine whether the firm with substantial market power "took advantage of" that power to eliminate or limit competition, it will focus more appropriately on whether the actual firm with market power derived any greater benefit from the conduct than would a firm without such power. If it did, the conclusion that it was "taking advantage of" that power, in the sense of deriving exclusionary benefits attributable to its power, would seem justified, although further inquiry would be required to assess the harm to competition and the justifications, if any, for the conduct. Secondly, it will examine "minor amendments", a corrective approach that would retain most of the current language, but refocus it on purpose and effect and, as Australia has done, explicitly provide for greater flexibility. Finally, the article will briefly consider whether s 36 should be entirely abandoned in favour of a statutory model that might be more consonant with the prevailing "abuse of dominance" approaches of many other jurisdictions.

\section{SECTION 36 AND THE COUNTERFACTUAL TEST}

As a starting point, it is useful to read s 36 as if "reading it for the first time", without regard to its current interpretation and the controversy surrounding the counterfactual. What are its principal textual elements, characteristics and apparent goals? Approaching s 36 in this fashion reveals why its "take advantage of" language has come to play such a critical role in differentiating between conduct that may harm competitors and that may harm competition, between merits-based superiority and non-merits-based exclusionary conduct. It also helps to frame the essential question for any prohibition of unilateral conduct: does the counterfactual interpretation of the "take advantage of" provision achieve these goals? 


\section{A Reading Section 36 "For the First Time"}

Section 36, as amended in 2001, states in relevant part: ${ }^{12}$

A person that has a substantial degree of power in a market must not take advantage of that power for

the purpose of-

(a) restricting the entry of a person into that or any other market; or

(b) preventing or deterring a person from engaging in competitive conduct in that or any other market; or

(c) eliminating a person from that or any other market.

The explicit elements of the offence are immediately apparent. Section 36 only applies to a person with "substantial market power", which, as already noted, reflects an appreciation on the part of its drafters for the principle that conduct by firms with substantial market power warrants distinctive treatment. There is no reference to "agreements" or "contracts", so s 36 appears to be targeted at unilateral conduct by such firms. Its operative language, shared with s 29 , associates it with exclusionary conduct - "restricting", "preventing" and "eliminating" are all terms associated with conduct that excludes, or otherwise impedes or disadvantages competitors. Despite this seeming concern for exclusion, however, the provision does not explicitly refer to "effects" and does not include an explicit efficiency defence. Instead, it focuses on purpose, and the purpose that seems to matter is the purpose to harm competitors - "a person" in the same "market" as the firm with market power. So without regard to s 36's "taking advantage" language, s 36 could be read to prohibit all conduct unilaterally undertaken by a firm with substantial market power for the purpose of harming a rival, regardless of the conduct's broader competitive effects, both harmful and beneficial.

If the statute was limited to just these features, it could easily be read too broadly. An essential aim of the competitive process is to best one's rivals. All firms, whether or not they possess market power, strategise to "eliminate the competition". With no further filtering mechanism, s 36 could support challenges to every act of a firm with market power that could conceivably be characterised as undertaken "for the purpose of" eliminating rivals, including obviously desirable actions, such as introducing new and superior products or services that wrest customers from the firm's rivals. This is the common and core challenge of all prohibitions of unilateral conduct by dominant firms. Competition will always yield winners and losers. Competition policy, therefore, must differentiate between the reduction in competition that can come from the operation of the competitive process itself and reductions occasioned by "improper" means, between what United States Judge Learned Hand once famously described as "superior skill, foresight and industry"13 and what commentator

12 Commerce Act 1986, s 36(2) (emphasis added).

13 United States v Aluminum Co of America 148 F 2d 416 (2d Cir 1945) at 430: "A single producer may be the survivor out of a group of active competitors, merely by virtue of his superior skill, foresight and industry. 
Robert Bork described as competition "on some basis other than efficiency". ${ }^{14}$ This is not because the dominant firm is "entitled" to respond to new competitive challenges - it is because it would be economically undesirable for the standards of liability to themselves inhibit or deaden its incentive to do so. There must therefore be some anticompetitive act and a consequent reduction of competition.

The sole element in s 36 left to accomplish this critical goal is its "take advantage of" requirement. With that added into the mix, s 36 appears intended to prohibit a firm with substantial market power from exercising that power for the purpose of harming its rivals. There must be a causal nexus between the exercise of power and a prohibited purpose. Section $36 \mathrm{~B}$ adds that "[t]he existence of any of the purposes specified in s $36 \ldots$ may be inferred from the conduct of any relevant person or from any other relevant circumstances." This ties up the package and highlights the connection between power, conduct and purpose. Adverse effects are the obvious, implicit concern, but are not expressly required as an element.

The seemingly sole means endorsed by the New Zealand Supreme Court to accomplish this important goal is the "counterfactual". Yet the language of s 36 does not compel it; indeed, by focusing almost exclusively on the "must not take advantage" language, the test seems to elevate the importance of a single statutory element over what appears to be the obvious and explicit core concern of the provision when read as a whole: conduct that is undertaken for exclusionary purposes. Although s 36 does not also refer in the alternative to "effects", as does s 27, "restricting", "preventing" and "eliminating" are effects-focused words that arguably invite at least some inquiry into effects, especially given the often close relationship between purpose and effects. ${ }^{15}$ Yet, in derogation of this text of s 36 , the counterfactual does not directly examine whether the dominant

In such cases a strong argument can be made that, although the result may expose the public to the evils of monopoly, the [Sherman] Act does not mean to condemn the resultant of those very forces which it is its prime object to foster: finis opus coronat. The successful competitor, having been urged to compete, must not be turned upon when he wins." See also Queensland Wire Industries Pty Ltd v The Broken Hill Pty Ltd (1989) 167 CLR 177 (HCA) at [24]: "Competition by its very nature is deliberate and ruthless. Competitors jockey for sales, the more effective competitors injuring the less effective by taking sales away. Competitors almost always try to "injure" each other in this way. This competition has never been a tort ... and these injuries are the inevitable consequence of the competition s 46 is designed to foster."

14 Robert H Bork The Antitrust Paradox (Basic Books, New York, 1978) at 138, cited with approval in Aspen Skiing Co v Aspen Highlands Skiing Corp 472 US 585 (1985) at 605.

15 As the United States Court of Appeals for the District of Columbia Circuit observed in the Microsoft case, United States v Microsoft Corp 253 F 3d 34 (DC Cir 2001) at 59: "Evidence of the intent behind the conduct of a monopolist is relevant only to the extent it helps us understand the likely effect of the monopolist's conduct." In support of this proposition, the court cited Chicago Board of Trade v United States 246 US 231 (1918) at 238: "... knowledge of intent may help the court to interpret facts and to predict consequences". See also McWane Inc v Federal Trade Commission 783 F 3d 814 (11th Cir 2015) at 840: "... evidence of the 'clear anticompetitive intent' behind an exclusive dealing program 'supports the inference that it harmed competition'." 
firm has engaged in conduct having the specified, prohibited purposes. It operates based solely on inferences.

Other interpretations are clearly available and could restore meaning to the overall language of the provision. For example, if read simply and literally, "taking advantage of" means benefiting from, as in "taking advantage of her superior strength and skill, she won a trophy at the tournament". It connotes conduct that provides a benefit to the firm, such as increasing its profits, which could not be realised by a firm lacking that "advantage". Read together with "restricting", "preventing" and "eliminating", it could be sensibly read to mean benefiting from the exercise of market power by engaging in conduct that harms rivals and helps to maintain or increase that power. The counterfactual seems to invert the language. Instead of focusing on the advantages flowing from the exercise of market power and how they were secured, it turns to an inquiry into the advantages of the conduct for a firm lacking it. The counterfactual thus seems ill-suited to play the role of differentiating "good" from "bad" conduct effectively. Even within the current language of s 36, alternative interpretations of "take advantage of" might better serve s 36's overall goals, while giving greater weight to its exclusionary conduct language.

\section{B Deconstructing the Counterfactual Test}

In its 0867 decision, the New Zealand Supreme Court defined the counterfactual test this way: ${ }^{16}$

[I]t cannot be said that a person in a dominant market position "uses" that position for the purposes of s 36 [if] he acts in a way which a person not in a dominant position but otherwise in the same circumstances would have acted.

It later described the test as a "comparison", one intended to lend predictability to the business planning of firms with substantial market power by providing them with a bright line indication of which conduct will transgress the provisions of s 36: if a firm without market power would undertake the same conduct, then it cannot be said that the firm with market power "took advantage of" that power for a prohibited purpose. Hence, a firm with market power can adopt any course of conduct without fear of challenge if a hypothetical firm in a competitive market might have reason to adopt it as well.

The counterfactual as so designed substitutes a hypothetical inquiry into the incentives of a firm without market power for an examination of the actual or probable effects of conduct undertaken by one that possesses it. It can be questioned on at least four grounds: (1) it does not involve any true "comparison"; (2) it relies on unsupported and unsupportable inferences; (3) it utilises incorrect

16 0867, above n 2, at [13], quoting Telecom Corp of New Zealand Ltd v Clear Communications Ltd [1995] 1 NZLR 385 (PC) [Clear] at 403. Clear was decided based on s 36's pre-2001 "use" language, and the events giving rise to 0867 occurred prior to 2001. But the Court in 0867 indicated that there was no difference in meaning between "use" and "take advantage of", at [1]: "... we conclude that the expressions 'use' and 'take advantage of' involve the same inquiry". 
assumptions about the nature of "purpose"; and (4) it draws unreliable conclusions about causation. In operation, all of these flaws are interrelated and call into question the counterfactual's ability to serve its intended purpose of consistently differentiating unreasonably exclusionary conduct.

\section{Comparative analysis without benchmarking}

The counterfactual cannot fairly be characterised as a method of "comparative" analysis. Although it purports to compare the likely purposes of a firm without market power to the purposes of a firm with market power, in actuality it undertakes no such comparison. As will be explored in the next section, instead the counterfactual relies on inferences drawn from the predicted behaviour of a non-dominant firm. To accomplish its task, the test demands that the plaintiff construct a hypothetical, alternate market, in which the market power of the defendant is stripped out. Its aspiration of isolating that single characteristic of the firm and imagining a non-dominant firm that "otherwise [is in] the same circumstances", however, is unlikely to be realised. A firm's substantial market power will likely be related to other attributes of the firm and the characteristics of the market, which might include conditions of entry, the firm's cost structure (for example, its fixed and variable costs), and the size and characteristics of the other firms in the market. Moreover, to construct the counterfactual market, it will often be necessary to study the workings of the actual market, but somewhat oddly: the direct benefit of that study is lost as it serves primarily to assist in the construction of an alternate hypothetical market, one that the Court itself has acknowledged "will depart substantially from the realities of the actual market in which the firm is dominant $" .{ }^{17}$ If it appears likely that the hypothetical firm in this highly altered and stylised market would undertake the same conduct, the counterfactual concludes that the firm with market power did not "take advantage of" its market power. In effect, the test reaches a determination that it took no greater "advantage" of its position than would a firm in a competitive market.

At least in its theoretical form, no comparison is actually undertaken - the laboratory version of the counterfactual is entirely a one-sided affair that provides no basis for reliable comparison. It does not explicitly inquire into the actual firm's contemporaneous documents and records to observe whether there is reason to believe that it acted for a proper or improper purpose, but rather only to help in the construction of the counterfactual market. ${ }^{18}$ Neither does it explicitly inquire into the

17 0867, above n 2, at [29].

18 Indeed, to satisfy the counterfactual's requirement that the hypothetical market must strip out all remnants of market power to ensure that the hypothetical competitive firm is "otherwise in the same circumstances" as the firm with market power, the parties and the court will necessarily need to devote considerable effort to understanding the actual market. Yet, having gathered such evidence, the court then substitutes an assessment of the probable conduct of the counterfactual firm for an assessment of the real one. By the point a court has gathered enough evidence about the actual market both to establish that the firm has substantial market power, s 36's initial element, and to control for and negate the characteristics of the market that may be linked to the defendant's possession of market power, however, it will likely have in hand the evidence needed to assess the probable or actual effect of the challenged conduct. 
effects of the challenged conduct to determine whether it was harmful to competition. This reveals an important and essential characteristic of the counterfactual: it relies on implicit inferences and presumptions, not on any actual comparison of the hypothetical and real world markets, to reach its conclusions. From the observation that a hypothetical firm without market power in a hypothetical market might undertake the same conduct, it infers that the dominant firm did so without any improper purpose and concludes that there can be no violation of $\mathrm{s} 36$.

If courts were inclined to conduct a revealing and truly comparative analysis, they could turn to a number of recognised techniques used in other areas of antitrust that involve more reliable benchmarks. For example, "before and after" modelling compares the performance of a market before and after allegedly anticompetitive conduct took place to observe changes in output, price or other dimensions of competition. Differences are controlled for, not baked in to the model as with the counterfactual. Absent reliable evidence of the market's performance before the conduct was adopted, an alternate technique is to look for a real world "yardstick" market, one that is similar in critical ways, but in which market power is absent. Again, differences are controlled for, not baked in to the model. In consummated merger analysis, for example, one might compare the post-merger market with the pre-merger market, or seek to predict how the market would have evolved but for the merger. ${ }^{19}$

If use of a counterfactual approach is perceived as necessary to any interpretation of $\mathrm{s} 36$, a "reverse counterfactual" model also could be imagined, in which a court would compare the observed effects of the conduct with the likely effects of the same conduct if it had been undertaken by a firm without market power. Such a comparison of all effects would provide a basis for a more direct measure of whether the firm with market power "took advantage of" its power - did it derive some benefit that a firm without power could not have secured? If so, did that benefit flow from the conduct's pro or anticompetitive effects? Perhaps this kind of focus on the dominant firm is what the Court intended, but its description of how the counterfactual market is to be constructed necessarily leads to a different emphasis. Any of these alternative approaches would provide more of a true comparison than the current version of the counterfactual and would focus on the more salient issue: the dominant firm's purposes and the effects of its conduct.

\section{Drawing unreliable inferences}

Contrary to how it is often presented, the counterfactual thus does not involve any true "comparison". Instead it relies on questionable inferences and presumptions that warrant closer examination. The operation of the counterfactual, and its reliance on inference, can be observed in

19 In contrast, in order to satisfy the "substantial lessening of competition" requirement of New Zealand's merger control provision, s 47, the analysis of a consummated merger would involve a comparison of the market as it actually performed post-merger with the market as it might have developed absent the merger. This, too, is sometimes referred to as a "counterfactual" test, but an actual comparison of the real market and the hypothetical one is undertaken. This does not appear to be the case under s 36 . 
several critical passages from the Supreme Court's 0867 decision. Citing the opinion of Heerey $\mathbf{J}$ in Boral, which arose in Australia, ${ }^{20}$ the Court endorsed the following as illustrating the "comparative inquiry": 21

If the impugned conduct has a business rationale, that is a factor pointing against any finding that conduct constitutes a taking advantage of market power. If a firm with no substantial degree of market power would engage in certain conduct as a matter of commercial judgment, it would ordinarily follow that a firm with market power which engages in the same conduct is not taking advantage of its power.

Note the explicit reliance on inference in the second sentence: from the fact that a firm without market power would have reason to adopt the same conduct, the court reasons, "it would ordinarily follow" that a firm with market power that does the same is not taking advantage of its market power. At this critical juncture in the operation of the counterfactual, no true comparison takes place. Indeed, this inferential leap lies at the heart of the counterfactual - and its reliability is highly debatable.

The essentiality of this reliance on inference becomes even more clear several paragraphs later in the 0867 decision, when the Court presents two corollary propositions: ${ }^{22}$

The essential point is that if the dominant firm would, as a matter of commercial judgment, have acted in the same way in a hypothetically competitive market, it cannot logically be said that its dominance has given it the advantage that is implied in the concepts of using or taking advantage of dominance or a substantial degree of market power. Conversely, if the dominant firm would not have acted in the same way in a hypothetically competitive market, it can logically be said that its dominance did give it the necessary advantage. This is because it can then reasonably be concluded that it was its dominance or substantial degree of market power that caused, enabled or facilitated its acting as it did in the actual market.

Both of these propositions are highly debatable and likely to be true only in specific and limited circumstances. The first wrongly infers that if a firm in a competitive market would have adopted the same practice, a firm with market power who adopts it cannot be said to be "taking advantage" of its market power. The proposition ignores the widely accepted fact discussed earlier: the consequences of the same conduct practised by a firm with market power will, especially when competition is at issue, be different when compared to a firm without it. As one commentator recently observed, it is a mistake to conclude from the fact that a business practice is "prevalent in

20 Australian Competition and Consumer Commission v Boral Ltd [1999] FCA 1318, (1999) 166 ALR 410 at [158].

21 0867, above n 2, at [26] (emphasis added). The Court's use of "ordinarily follow" also invites inquiry into whether there might be exceptions and whether the inference can be rebutted.

22 0867, above n 2, at [31] (emphasis added). 
competitive markets" that a firm "cannot readily use these practices to harm competition, either at all or on balance after accounting for efficiencies" and hence to further conclude that they cannot violate competition laws. Such prevalence "does not preclude the possibility that firms can also use those practices to obtain or maintain market power, and that those practices harm competition on balance when employed by firms exercising market power". ${ }^{23}$ Almost by definition, the effects of the same conduct will be different depending on a firm's market power or prospect of obtaining or maintaining it. And because the effects of the conduct may well be different, the respective incentives of the firms with and without market power will also be different and hence should be examined before any conclusion can be inferred about their respective purposes and the effects of their conduct. While both firms may share the incentive to achieve efficiency, the dominant firm may also have distinct and unique incentives linked to the anticompetitive potential of the same conduct. Moreover, its ability to "take advantage" of its power to secure anticompetitive benefits may provide a more influential incentive for the dominant firm, one that will be irrelevant to the firm without market power. This kind of evaluation of incentives is very familiar to competition lawyers and economists, who typically focus intently on those incentives when evaluating other kinds of competitively sensitive conduct, such as collaborations and especially mergers. The first inference in 0867 , therefore, is very likely to be mistaken in many cases, precisely because the real world firm has market power.

Likewise, the second, converse inference is also likely to be mistaken in many cases, albeit for different reasons. The absence of a reason for the firm without market power to undertake the conduct does not mean that it was necessarily undertaken by a firm with market power for an anticompetitive purpose. Recall that the counterfactual relies upon a theoretical construct - a market stripped of all of the characteristics of the "real world" market that might contribute to the firm's market power. Can it reliably be predicted that simply because conduct may lack any utility for a firm in such a hypothetical world that its only value for a firm with market power will be to achieve some anticompetitive purpose? Again the Court's answer disregards the unique circumstances of the firm with substantial market power. Although those circumstances may mean that it is uniquely suited to act for an anticompetitive purpose, as predicted by the counterfactual, they may also mean that it is better positioned to achieve efficiencies unavailable to the firm lacking market power, or at least that is in different "circumstances". There may be, for example, efficiencies available to the firm with market power, such as achieving scale economies, that are not available to the firm without it. There may also be various kinds of competitively beneficial arrangements that as a

23 Baker, above n 9, at 17-18. Baker goes on to argue at 18: "Nor does the prevalence of certain practices, particularly exclusionary practices, in competitive markets support an inference that the same practices, when challenged by antitrust enforcers, typically have an efficiency motive, which antitrust enforcement would chill. Even if many or most instances of a practice benefit competition or are competitively neutral, that does not mean that the subset of instances challenged in court (by virtue of facts suggesting the possibility of competitive harm) typically benefit competition on balance, or even benefit competition at all." (emphasis in original) (footnotes omitted). 
practical matter are available only to the dominant firm, not to a non-dominant firm, because of their desirability to third parties with whom the firm with market power contracts. For example, exclusive supply arrangements only possible because of the dominant firm's production capacity might increase predictability and reduce costs for a customer of the dominant firm. Hence, the counterfactual might wrongly conclude that a practice unlikely to be undertaken by a hypothetical firm that lacks market power is motivated by an improper purpose when practised by a dominant firm. It may be attractive to the dominant firm because it is beneficial to its suppliers or customers, who would be unlikely to realise those benefits if the same terms were offered to them by a nondominant firm.

As was noted with respect to the counterfactual's purported reliance on comparison, if an approach based on inference is desirable, there are more reliable and informative inferences that could be used. As is acknowledged by s 36B, conduct and purpose are interrelated. Hence, "taking advantage" could be defined with reference to the actual conduct of a firm with substantial market power, and that in turn could provide a basis for inferring a prohibited purpose. To do so, New Zealand could turn to accepted definitions from other jurisdictions, especially the idea of "attempting to exclude rivals on some basis other than efficiency". ${ }^{24}$ If a firm with substantial market power engages in non-merits based competitive strategies, it could fairly be inferred that it acted with a prohibited purpose. Such an approach would better harmonise s 36 with other features of New Zealand's Commerce Act 1986, especially s 36B, and would be more consistent with international norms. Again, as with an alternate form of counterfactual test, the goal would be to refocus attention much more directly on the dominant firm.

\section{Erroneous inference of permissible purpose}

As noted, in operation the counterfactual relies on inference: from the prediction that a hypothetical firm without market power would have adopted the conduct, it infers a non-prohibited (that is, non-exclusionary) purpose to the conduct, a purpose unrelated to "taking advantage of" market power. Whether s 36 requires a showing of "substantial" or "sole" purpose, ${ }^{25}$ this approach once again ignores the distinctiveness of the firm with market power and the potential differences between its incentives and the incentives of a counterfactual non-dominant firm. As already noted, although the dominant firm might share a beneficial purpose for adopting the conduct with the non-

24 For example Aspen Skiing Co v Aspen Highlands Skiing Corp, above n 14, quoting Bork, above n 14. See also Phillip E Areeda and Herbert Hovenkamp Antitrust Law (4th ed, Aspen Publishers, New York, 2015) vol 3 at 98 (proposing a general definition of monopolistic conduct).

25 Section 2(5)(b) of the Commerce Act 1986 defines "purpose" as meaning "substantial purpose" (emphasis added). See also Mark Lyons Pty Ltd v Bursill Sportsgear Pty Ltd (1987) 75 ALR 581 (HCA) at [44]: "... it is sufficient that an applicant prove that one of the purposes actuating a respondent - provided only that this one purpose was substantial - was the deterrence or prevention of competition. It is not necessary to prove that this was the sole purpose." 
dominant firm (perhaps it might even realise greater benefits), it might also and simultaneously have a substantial anticompetitive purpose; one that could derive from its ability to take advantage of its market power and thus be unavailable (and hence irrelevant) to the non-dominant firm. In other words, the substantial purpose of the non-dominant firm will not necessarily be a valid predictor of the substantial purpose of the dominant firm.

The counterfactual will miss this possibility because it does not examine any real world evidence of purpose or effects. In essence, although a finding that the conduct is attractive to a competitive firm might suggest a procompetitive purpose, it does not eliminate the possibility that the dominant firm may have a distinct and even more valuable purpose in adopting the conduct, one that might well not be available to the hypothetical non-dominant firm. And that alternate purpose might be pro or anticompetitive. The counterfactual test will perform poorly as a basis for inferring substantial purpose, therefore, in circumstances where the dominant firm's purposes are likely to differ significantly from the non-dominant firm's purposes, and that could be the far more likely scenario in many cases involving firms with market power.

\section{Assuming causation where there may be none}

Recall that the goal of the counterfactual is to serve as a sorter, permitting courts, agencies and parties to differentiate exclusion occasioned by competition on the merits from exclusion occasioned by competition on some basis other than efficiency. It seeks to accomplish that by filling the "causation" gap in s 36: by determining whether there is a link between a firm's market power and its conduct.

Given the internal limitations of the test, however, it seems unlikely to provide a consistently reliable basis for establishing or rejecting causation in many cases. It will wrongly conclude causation is lacking in a wide variety of cases of "mixed" or "multiple" purposes, where both a competitive firm and a firm with market power may share an interest in pursuing the same conduct. It may also wrongly conclude that there is no causation when a firm in a competitive position would not likely adopt a particular strategy, even though it might still be attractive to a firm with market power for reasons unrelated to its tendency to eliminate rivals. These weaknesses of the counterfactual as a test of causation become even more apparent when it is examined through the lens of decision theory.

\section{Applying a Decision-Theoretic Approach to Assessing the Counterfactual}

Economics has influenced competition policy not only by informing the analytical tools we use to assess the competitive consequences of conduct, but by providing a methodology to specify rules of liability. "Decision theory" uses economic reasoning to aid in the selection of "optimal" legal rules, defined as rules that minimise total social costs. It seeks to accomplish that goal by evaluating 
"error costs", the incidence and consequences of "false positives" and "false negatives", ${ }^{26}$ as well as the direct or administrative costs of the legal decision process that is associated with any specific rule. False positives - mistaken instances of liability - can be harmful because they will tend to deter both the defendant and others from undertaking similar conduct, even though it may not be harmful. Conversely, false negatives - mistaken instances of non-liability - can amplify incentives to undertake harmful conduct for both the defendant and others, harming competition and consumers. The costs of the decision making process are also relevant, and will include the costs of gathering and processing the information necessary to conduct the analysis mandated by any specific legal rule, as well as the direct decision costs. Bright line rules can fare well on the "cost" dimension, but if prone to error can lead to an increased incidence of erroneous decisions in either direction. $^{27}$

Error cost analysis has had a significant impact on the global dialogue about standards for judging single-firm conduct under competition laws. ${ }^{28}$ In the United States especially, the Supreme Court has been openly concerned about false positives and the unique costs associated with the features of the American litigation system - relatively broad discovery and class actions - and the United States' antitrust private right of action, which provides for the recovery by a prevailing private plaintiff of treble damages, attorneys' fees and the costs of suit. ${ }^{29}$

The counterfactual fares poorly when evaluated under such a decision-theoretic approach. As has already been explained, it will be prone to false negatives, reaching likely frequent, incorrect conclusions that conduct is benign or beneficial when it may be harmful if practised by a firm with substantial market power. And it will do this systematically, precisely because it equates the incentives of firms without and with market power in lieu of any consideration of market power and

26 Sometimes referred to as "false convictions" and "false acquittals".

27 See generally Andrew I Gavil "Burden of Proof in U.S. Antitrust Law" in Issues in Competition Law and Policy (ABA Antitrust Section, Chicago, 2008) 125 at 129-131; and Andrew I Gavil, William E Kovacic and Jonathan B Baker Antitrust Law in Perspective: Cases, Concepts and Problems in Competition Policy (2nd ed, West Academic Publishing, St Paul, 2008) at 77-80.

28 See for example Steven C Salop "Exclusionary Conduct, Effect on Consumers, and the Flawed ProfitSacrifice Standard" (2006) 73 Antitrust LJ 311; Frederick Beckner III and Steven C Salop "Decision Theory and Antitrust Rules" (1999) 67 Antitrust LJ 41; and Steven C Salop and R Craig Romaine "Preserving Monopoly: Economic Analysis, Legal Standards, and Microsoft" (1999) 7 Geo Mason L Rev 617 at $653-$ 655 .

29 See for example Verizon Communications Inc v Law Offices of Curtis V Trinko 540 US 398 (2004) at 414: "The cost of false positives counsels against an undue expansion of $\S 2$ liability."; Matsushita Electric Industrial Co v Zenith Radio Corp 475 US 574 (1986) at 594: Mistaken inferences and the resulting false condemnations "are especially costly, because they chill the very conduct the antitrust laws are designed to protect". These features of the United States system are also described in Andrew I Gavil and Harry First The Microsoft Antitrust Cases: Competition Policy for the Twenty-First Century (MIT Press, Cambridge (MA), 2014) at 134-138. 
how it influences actual purposes and effects. Indeed, it seeks to control for and eliminate consideration of those purposes and effects by constructing a counterfactual world that, by design, may not take sufficient account of the unique and possibly mixed incentives of the firm with market power. ${ }^{30}$ Also, as explained, the test could produce false positives (although these cases are less likely to be brought), because it fails to consider the possibility that there may be efficiencies available to a firm with market power that are not available to firms without power. Only the simplest of cases are likely to be decided correctly under the counterfactual - cases involving either naked exclusion or cases involving an obvious efficiency justification and a very low probability of harm. These kinds of cases, however, are perhaps unlikely to be brought or litigated because the outcome is so obvious, and they have not proven to be difficult for other jurisdictions to decide under effects-focused approaches. The more complex, nuanced, and "mixed purpose" cases that may be more likely to lead to disagreement and litigation will be far more susceptible to error.

It is also a myth that the counterfactual provides a bright line of predictability and hence a costeffective means of evaluating conduct. First, it does not avoid the threshold inquiry into substantial market power, which will still be undertaken in all cases under s 36. Also, as is evident in cases like 0867 and Datatails, ${ }^{31}$ constructing the counterfactual can require extensive industry information gathering and fact-finding. The information-gathering process, however, will be prone to inefficiency given that the information is not relied upon for its highest value: to illuminate the actual purposes and effects of the firm with market power. The counterfactual thus can involve significant cost and uncertainty.

Finally, the counterfactual is not likely to serve the purpose of preserving long-term, dynamic efficiency, an argument that has been offered in its defence. ${ }^{32}$ Similar arguments are often made in opposition to standards for judging unilateral conduct that are perceived as relatively more interventionist, but these arguments are prone to exaggeration and lack empirical support. First, and quite ironically, most competition law enforcement cases brought against dominant firms involve their responses to new entry, not innovative initiatives they have undertaken on their own. Although it is common in litigation for dominant firms to present themselves as "innovators", enforcement efforts have been prompted far more frequently by their strategic responses to innovators who have challenged their dominance. ${ }^{33}$ That does not necessarily mean that their response is anticompetitive,

30 For similar arguments that the counterfactual will tend to be "under-inclusive and generate false negatives", see Cento Veljanovski "The Flawed Market Power Counterfactual" (2013) NZLJ 247 at 248. Veljanovski observes, as this article also argues, that the counterfactual wrongly dismisses the significance of the defendant's market power and the circumstances that give rise to it.

31 Telecom Corporation of New Zealand Ltd v Commerce Commission [2012] NZCA 278.

32 See for example Sumpter, above n 8, at 127-130.

33 For a discussion of this phenomenon in the Microsoft antitrust cases, see Gavil and First, above n 29, at $327-328$. 
but it may suggest that, even if the response involves some true "innovation", it might not have occurred but for the competitive challenge. An important countervailing concern for competition policy, therefore, is the preservation of the incentives of firms who would challenge dominant firms. This will be especially true in a small-market economy such as New Zealand. As the Chairman of the Commerce Commission, Dr Berry, has observed, many of its industries are characterised by high degrees of concentration, significant barriers to entry and sub-optimal levels of production efficiency. ${ }^{34}$ Competitive challenges in such a setting are especially valuable and a standard for judging unilateral conduct that tends toward protecting the status quo may well have adverse longterm consequences for the economy's dynamism.

The argument also reflects a view that monopoly is more likely to spur innovation than competition. This is a reprise of a long-standing debate invoking the work of economists Joseph Schumpeter and Kenneth Arrow. As one thought-provoking survey concluded, however, the economic literature does not support an a priori assumption that monopoly will best promote innovation. "As a general rule, competition does not just lead firms to produce more and charge less; it encourages them to innovate, as well. Competition supplies a powerful motive for innovation. "35 Moreover, the more important question is whether thoughtful and targeted antitrust enforcement can promote innovation: ${ }^{36}$

The modern economic understanding about the relationship between competition and innovation goes beyond Schumpeter and Arrow by suggesting ways for antitrust rules and enforcement efforts to target types of industries and types of conduct. Through such selection, antitrust intervention can systematically promote innovation competition and pre-innovation product market competition, which will encourage innovation, without markedly increasing post-innovation product market competition, and, thus, without detracting from the pro-innovation benefits.

Case-by-case analysis of market conditions and incentives, therefore, is likely to provide a better methodology for assessing concerns about innovation than ex ante blanket presumptions.

\section{LOCATING THE COUNTERFACTUAL IN THE OVERALL FRAMEWORK OF NEW ZEALAND'S COMMERCE ACT}

As it is currently being interpreted, s 36 is an admixture of unique characteristics and features drawn from other parts of the Commerce Act 1986. This Part examines its place within the broader framework of the Commerce Act and its interrelationship with other portions of the Act. It poses the broad questions: do the various provisions of the Commerce Act fit and work well together? Do

34 Berry, above n 2, at 127-128.

35 See Jonathan B Baker "Beyond Schumpeter vs. Arrow: How Antitrust Fosters Innovation" (2007) 74 Antitrust LJ 575 at 587 (footnotes omitted).

36 At 589 
they work in harmony, the way the components of a well-functioning statutory scheme should, or is there dissonance? The discussion centres on ss 27, 29, 36 and 47.

\section{A Section 36's Relationship to the Other Provisions of the Act}

The counterfactual test creates an uncomfortable and unnecessary tension across ss 27, 29, 36 and 47, undermining their collective cohesiveness. Section 27 prohibits an anticompetitive contract or agreement that has the "purpose, or has or is likely to have the effect, of substantially lessening competition in a market". It is New Zealand's general prohibition of anticompetitive concerted action and shares some key features with the similar prohibitions of s 1 of the Sherman Act in the United States and Article 101 of the Treaty on the Functioning of the European Union (TFEU), which also target anticompetitive concerted action. ${ }^{37}$ Although s 29 similarly is addressed to concerted action, like s 3 of the Clayton Act in the United States, it is directed at exclusionary agreements, most particularly exclusionary refusals to deal directed at competitors. However, it more specifically structures the burden of proof than s 27 . Whereas proof of a purpose or effect to substantially lessen competition can establish an offence under s 27, s 29 requires proof only of a purpose to prevent, limit or restrict competition. At that point the burden shifts from the plaintiff to the defendant. A defendant can rebut the presumption: ${ }^{38}$

$\ldots$ if it is proved that the provision does not have the purpose, or does not have or is not likely to have

the effect, of substantially lessening competition in a market.

In cases resting upon evidence of effects, this language appears to reverse the burden that falls to the plaintiff in s 27: instead of effect being part of the prima facie case, absence of effect can be used as a statutory defence.

Section 36 shares a common focus on exclusionary conduct and a requirement of an exclusionary "purpose" with s 29, but it is otherwise distinct in structure from both ss 29 and $27 .{ }^{39} \mathrm{It}$ neither includes an adverse effect requirement nor an "absence of purpose or effect" defence like s 29. So in contrast to both sections addressing agreements, it contains no explicit reference to effects. Also unique are its applicability to unilateral conduct, its explicit requirement of substantial market power, and its reliance on a "take advantage of" causation provision.

37 Although s 1 uses the common law formulation of "restraint of trade", the United States' Clayton Act uses "substantial lessening of competition". In the United States "unreasonable restraints of trade" and "substantial lessening of competition" have largely been read as coextensive effects standards. Article 101 prohibits agreements "which have as their object or effect the prevention, restriction or distortion of competition within the internal market".

38 Section 29(1A)

39 Section 29 may be repealed under pending amendments to the Commerce Act 1986. If the repeal becomes effective, s 36 will become the sole provision of the Act explicitly directed at exclusionary conduct. 


\section{B The Uncomfortable "Fit" of the Counterfactual}

How does s 36's counterfactual fit into this broader statutory scheme? In operation, it is not like anything found in the case law regarding ss 27 or $29 .{ }^{40}$ Conceptually, its threshold requirement of substantial market power might draw it closer to $\mathrm{s} 27$, because market power is a likely requirement for proving substantial lessening of competition in many cases. But that will likely depend on how substantial lessening of competition is interpreted and proven, and whether market power is viewed as a matter of degree. Its focus on exclusion, on the other hand, draws it closer to s 29 , but it lacks any comparable defence directed at purpose and effect. As interpreted to include the counterfactual test, s 36's closest analogue is perhaps prospective merger analysis under s 47 . But s 47 does not include any "purpose" test; instead, like s 27, s 47 focuses solely on whether an acquisition "would have, or would be likely to have, the effect of substantially lessening competition in a market". ${ }^{41}$ To the degree s 47 uses a counterfactual approach, in operation it is quite different from the process used under s 36 , precisely because it is prospective and because it focuses solely on developing a true comparison of the market with and without the merger. ${ }^{42}$

The end result is a system that seems unbalanced, internally inconsistent and unlikely to fully serve the overarching goal expressed in the Act: "to promote competition in markets for the longterm benefit of consumers within New Zealand". ${ }^{43}$ One might take as a general rule of thumb that competition prohibitions should analyse like harms and like benefits under like approaches. Similar threats of anticompetitive effect, whether collusive or exclusionary, ought to be treated alike since they pose similar competitive threats. For example, guided by economic analysis, one might expect to see methodological similarity in the treatment of exclusionary boycotts, exclusionary distribution practices (such as exclusive dealing and tying), and vertical mergers that threaten to impair rival access to inputs or customers. This would provide for a common evolution of techniques and standards for assessing exclusionary conduct across all three provisions. But that is not the case under the Commerce Act. Each of these kinds of conduct, though sharing a common set of

40 Section 27 could also involve prospective analysis where the Commission seeks an injunction to stop an agreement in its infancy. However, in contrast to s 47, s 27 likely would require an analysis of purpose.

41 Section 47(1).

42 For a discussion of the operation of the counterfactual under merger analysis in New Zealand, see Berry, above n 2, at 146-149. See also Commerce Commission Mergers and Acquisitions Guidelines (July 2013) at 18: "To assess whether a substantial lessening of competition is likely requires us to compare the likely state of competition if the merger proceeds (the scenario with the merger, often referred to as the factual); with the likely state of competition if it does not (the scenario without the merger, often referred to as the counterfactual); and determine whether competition would be substantially lessened comparing those scenarios."

43 Commerce Act 1986, s 1A. The importance of this provision and its legislative history are noted in Berry, above $\mathrm{n} 2$, at $129-130$. 
economic issues, will likely be analysed differently, leading to a lack of internal cohesiveness and consistency that undermines overall predictability and certainty.

Section 36's reliance on the counterfactual serves to further isolate it within this overall framework. The end result is that s 36 stands alone methodologically, and seems poorly integrated with the Act's other competition-focused provisions, especially those that similarly address concerns with exclusion.

\section{THE COUNTERFACTUAL TEST IS AN ANOMALY IN THE GLOBAL COMPETITION POLICY COMMUNITY}

\section{A The Predominance of Effects-Based Analysis}

As noted at the outset of this article, the cornerstone principle that undergirds all prohibitions of single-firm conduct is that market power matters. Most jurisdictions, therefore, use some variation of an effects-based approach to the examination of single-firm conduct. They recognise that the competitive effects of a firm's conduct are likely to differ depending upon its market power. Although the relevant evidence of power, effects, conduct and purpose all tend to be interrelated, many formally begin the inquiry by assessing the market power of the firm, then turn to an examination of the conduct. This "power + conduct" formula, with some variations, is common across many jurisdictions and links the United States prohibition of monopolisation ${ }^{44}$ with the abuse of dominance model used in the European Union ${ }^{45}$ and many other jurisdictions. ${ }^{46}$ Typically, effects are proven based either on evidence of actual effects, when it is available, or reasonable inferences drawn from some combination of evidence of power, purpose and conduct. ${ }^{47}$

44 In the United States "[i]t is settled law that ... [monopolisation under s 2 of the Sherman Act] requires, in addition to the possession of monopoly power in the relevant market, 'the willful acquisition or maintenance of that power as distinguished from growth or development as a consequence of a superior product, business acumen, or historic accident"': Verizon Communications Inc v Law Offices of Curtis V Trinko, above n 29, at 407, quoting United States v Grinnell Corp 384 US 563 (1966) at 570-571.

45 Article 102(a) TFEU also prohibits "exploitative" abuses, specifically "directly or indirectly imposing unfair purchase or selling prices or other unfair trading conditions," which would fall outside the prohibition of monopolisation in the United States.

46 For a discussion, see Gavil, Kovacic and Baker, above n 27, at 582-587 and 718-722.

47 As revealed through a survey conducted by the International Competition Network (ICN), some jurisdictions use a "formalistic, bright line" approach to assessing abuse of dominance, whereas others use an "effects-based" test. Albeit in different ways, both seek to evaluate the likely effects of conduct. Bright line approaches use presumptions to reach the conclusion that certain kinds of conduct, when undertaken by a dominant firm, are probabilistically likely to be anti or procompetitive based on certain market factors. The survey also observed, however, that "most jurisdictions apply a hybrid approach that combines a formalistic approach with varying degrees of analysis of effects, usually using rebuttable presumptions". See International Competition Network Unilateral Conduct Working Group "Unilateral Conduct Workbook Chapter 1: The Objectives and Principles of Unilateral Conduct Laws" (paper presented at the 11th Annual ICN Conference, Rio de Janeiro, April 2012) at [33]-[34]. The Workbook also observes at [43] that the 
In making the initial inquiry into market power, most jurisdictions rely on the traditional process of defining a relevant market, calculating a market share, and inferring market power from a "high" market share, although the thresholds can vary. An evaluation of conditions of entry is also common and it is widely accepted that market share alone may not be a reliable indicator of market power. This approach to demonstrating market power can be understood in legal terms as using circumstantial evidence and inference to establish a presumption of market power. Increasingly, however, jurisdictions also look to more "direct" evidence to establish market power, such as indications that a firm actually exercised its power in its pricing or other market decisions, or by actually excluding rivals. Hence evidence of power and effects cannot be entirely differentiated power is a precondition to effects, and evidence of effects can be integral to the initial inquiry into power and will tend to address both prongs of the typical standard, power and adverse effects. ${ }^{48}$

Once the initial inquiry into power suggests that the firm is fairly characterised as a monopolist, dominant firm, or otherwise as possessing substantial market power, most jurisdictions move on to an inquiry into the conduct's probable or actual effects on competition - both pro and anticompetitive. Typically, this involves an examination of: (1) the conduct under evaluation; (2) whether it tended to impair, eliminate or possibly enhance competition; ${ }^{49}$ and (3) whether it increased or facilitated the continued exercise of, or insulated from erosion, the firm's market power. Circumstantial evidence and inferences can be used to support a finding of probable harm, but as noted below, those inferences are drawn from factors that directly relate to the dominant firm, the market in which it operates and its conduct. Although some jurisdictions formally claim that they will "balance" any pro and anticompetitive effects, true "balancing" is highly unusual in the sense of quantifying and comparing welfare losses and gains. Most cases instead are resolved based on an assessment of the strength of the evidence of probable or observed consumer harm.

Although s 36 conforms to the first step to some degree - it begins with an assessment of market power - in its reliance on counterfactual analysis it deviates substantially from the global norm in its

effects-based approach "allows for an analysis of the circumstances in the particular case, and is therefore particularly suitable where neither economic theory nor empirical research predicts ex-ante a procompetitive or exclusionary explanation for a certain type of conduct with a high degree of certainty". The Workbook summarises the results of responses to a 2007 ICN questionnaire, and reflects responses from 35 ICN members and 14 non-governmental advisors.

48 This was the approach taken by the United States Court of Appeals for the District of Columbia Circuit in the Microsoft case. See United States v Microsoft Corp, above n 15 (finding that both the circumstantial evidence (market share) and the direct evidence (conduct) both supported the conclusion that Microsoft had substantial market power and was properly characterised as a "monopolist").

49 The "mechanism" of exclusion is critical to the inquiry. It will be essential to know, for example, whether the conduct raised rivals' costs or reduced rivals' revenues. Similarly, it will be important to know if the conduct lowered the dominant firm's costs, or otherwise improved its products, services or distribution. Understanding the direct impact of the conduct will inform the ultimate conclusion about whether and if so how it affected competition. 
approach to the second step, the evaluation of the actual or probable anticompetitive effects of specific conduct. The counterfactual test as applied substitutes a hypothetical inquiry into the conduct's possible efficiencies if practised by a non-dominant firm for the more important question of its probable effects, good or bad, when practised by a particular, dominant firm in an actual market. Paradoxically, it strips out all of the evidence deemed most relevant to the effects inquiry in other jurisdictions: the dominant firm's market power, the key structural characteristics of the market and the firm's cost structure. Although evidence that could support an inference of probable anticompetitive effects, or of actual effects, is likely to surface during the inquiries necessary to establish market power and to construct the counterfactual market, it is neither the focus of the inquiry nor likely to prove dispositive.

As discussed above, the counterfactual also trades an inquiry into the dominant firm's actual motivations and the conduct's probable effects for a hypothetical inquiry centred on inferences drawn from the probable behaviour of an imaginary non-dominant firm. Moreover, as has been widely recognised by commentators, it does not attempt to assess whether the actual or likely anticompetitive effects are more substantial than any realised efficiencies. It therefore functions as an "any efficiency by a non-dominant firm" standard, which, as already argued, turns on unreliable inferences: (1) if a non-dominant firm would adopt the conduct, by inference the conduct is deemed harmless, and by double-inference it is deemed harmless even when practised by the dominant firm; and (2) if a non-dominant firm would not adopt the practice, by inference it is deemed harmful, and by double-inference it is presumed that when practised by the dominant firm it must be "taking advantage" of its market power.

Although New Zealand's competition law and the cases interpreting it look to the Australian competition laws and cases, the use of the counterfactual test appears to be more stringent and less flexible than the approaches adopted by the Australian courts. ${ }^{50}$ For example, the Australian High Court has discussed two additional tests, the "purpose test"51 and the "material facilitation test", 52

50 See Scott, above n 2, at 262-263, 274-276.

51 Although the majority of the High Court of Australia did not adopt this test when they found the defendant had breached s 46, the market power and purpose test was discussed by Deane $\mathrm{J}$ in Queensland Wire Industries Pty Ltd v The Broken Hill Pty Ltd, above n 13, at 197-198. Deane J noted that the defendant's refusal to supply materials to a competitor other "than at an unrealistic price was for the purpose of preventing QWI from becoming a manufacturer or wholesaler of star pickets. That purpose could only be, and has only been achieved by such a refusal of supply by virtue of BHP's substantial market power ... In refusing supply in order to achieve that purpose, BHP has clearly taken advantage of that substantial power in that market."

52 The material facilitation test was discussed by the High Court of Australia in Melway Publishing Pty Ltd v Robert Hicks Pty Ltd, above n 2, at 51, noting that "it may be proper to conclude that a firm is taking advantage of market power where it does something that is materially facilitated by the existence of the power. To that extent, one may accept the submission made on behalf of the ACCC ... that s 46 would be contravened if the market power which a corporation had made it easier for the corporation to act for the proscribed purpose than otherwise would be the case." 
which were codified in an update to the Australian statute. ${ }^{53}$ Yet in 0867 , the New Zealand Supreme Court sought to rationalise sole reliance on the counterfactual by arguing that these alternate tests are in fact mere variations of it. ${ }^{54}$

Although a comprehensive canvassing of the world's competition laws is beyond the scope of this article, those laws are reflected in the policy statements and guidelines adopted by a variety of enforcement agencies around the world, including the European Commission (EC), the Canadian Competition Bureau (CCB), and the United Kingdom's Competition and Markets Authority (CMA), ${ }^{55}$ each if which has issued formal guidance documents in connection with their prohibitions of unilateral conduct by dominant firms. ${ }^{56}$ None appear to use an analytical approach like the counterfactual as it is applied in New Zealand. To the contrary, in their guidance documents, it is clear that all three jurisdictions focus on an examination of the market in which the dominant firm operates, and the actual or likely effects of its conduct in that market. This is not surprising given the interdependence of power, conduct and effects. And although these other jurisdictions rely on inferences, those inferences are drawn from the power and conduct of the dominant firm and the characteristics of the market in which it operates, not a hypothetical non-dominant firm. Indeed, as has been argued throughout this article, it is precisely because the effect of a firm's conduct on competition is a function of its power that jurisdictions include prohibitions of single-firm conduct. It is anomalous, therefore, to have such a prohibition and then to interpret it in such a way as to eschew consideration of effects based on the most probative evidence.

For example, the EC's 2009 Guidance begins with an assessment of market power. If it is present, the inquiry turns to an evaluation of competitive effects, defined as "anti-competitive foreclosure". ${ }^{57}$ Among the relevant factors considered are the position of the dominant undertaking,

53 These alternate tests have been discussed in detail elsewhere and repeating that examination is beyond the scope of this article. See for example, Berry, above n 2, at 141-142; and Scott, above n 2, at 262-263.

54 See 0867, above n 2, at [30].

55 The current guidelines were adopted by the United Kingdom's previous enforcement arm, the Office of Fair Trading (OFT), which was combined with the previous Competition Commission and superseded by the CMA in 2014. The Board of the CMA has specifically adopted the OFT guidance on abuse of dominance. See Office of Fair Trading Abuse of a dominant position: Understanding competition law (OFT402, December 2004).

56 See for example EC Guidance on Abuse of Dominance, above at 4, at [2]. The document's purpose is "to provide greater clarity and predictability as regards the general framework of analysis which the Commission employs in determining whether it should pursue cases concerning various forms of exclusionary conduct and to help [dominant] undertakings better assess whether certain behaviour is likely to result in intervention by the Commission under Article 82." Due to subsequent revisions to the Treaty, all references to art 82 are now applicable to art 102 TFEU.

57 At [19]-[22]. For further analysis of anticompetitive foreclosure, see Steve C Salop, Sharis A Pozen and John R Seward "The Appropriate Legal Standard and Sufficient Economic Evidence for Exclusive Dealing Under Section 2: The FTC's McWane Case" (Georgetown Law Faculty, Paper 1365, 2014). 
the conditions in the relevant market, the position of the dominant firm's competitors, the position of customers and suppliers, the extent of the allegedly abusive conduct, possible evidence of actual foreclosure and direct evidence of any exclusionary strategy. ${ }^{58}$ In assessing these factors, as well as other relevant evidence specific to the conduct, the EC uses what it describes as a "counterfactual" approach. In contrast to s 36's version of a counterfactual, however, the EC's approach rightly focuses on the actual or likely impact of the conduct in the relevant market, not inferences based on a hypothetical firm in a competitive market: ${ }^{59}$

This assessment will usually be made by comparing the actual or likely future situation in the relevant market (with the dominant undertaking's conduct in place) with an appropriate counterfactual, such as the simple absence of the conduct in question or with another realistic alternative scenario, having regard to established business practices.

The Guidance further notes that: ${ }^{60}$

There may be circumstances where it is not necessary for the Commission to carry out a detailed assessment before concluding that the conduct in question is likely to result in consumer harm.

It explains: ${ }^{61}$

If it appears that the conduct can only raise obstacles to competition and that it creates no efficiencies, its anticompetitive effect may be inferred. This could be the case, for instance, if the dominant undertaking prevents its customers from testing the products of competitors or provides financial incentives to its customers on condition that they do not test such products, or pays a distributor or a customer to delay the introduction of a competitor's product.

The Guidance, therefore, focuses on an assessment of effects, both anti and procompetitive, evaluated based on the actual market circumstances. It also endorses use of a counterfactual and appropriate reliance on circumstantial evidence and inferences in establishing harm. But these inferences are to be drawn from evidence that relates directly to the dominant firm and the market in which it operates.

The EC Guidance's treatment of efficiencies is especially telling when compared to s 36's counterfactual approach. It requires direct evidence and does not contemplate drawing inferences from the likely behaviour of a hypothetical, non-dominant undertaking. ${ }^{62}$ If a dominant undertaking has engaged in conduct likely to have anticompetitive effects, it bears the burden of "demonstrating"

58 EC Guidance on Abuse of Dominance, above at 4, at [20].

59 At [21].

60 At [22]

61 At [22].

62 At [28]-[31]. 
with "a sufficient degree of probability, and on the bases of verifiable evidence" that those efficiencies "have been, or are likely to be, realized as a result of the conduct". ${ }^{63}$ This focus on the causal link between the dominant firm's conduct and efficiencies starkly differentiates the EC's approach from the hypothetical approach associated with New Zealand's counterfactual. As already argued, rather than inferring that the dominant firm's conduct will yield efficiencies based on the predicted behaviour of a hypothetical non-dominant firm, the EC's Guidance asks the more salient question: did the dominant firm's conduct actually yield any efficiencies?

It is noteworthy that the EC's focus is on actual or likely anti and procompetitive effects, assessed based on the characteristics of the market and the dominant undertaking's power and conduct. It does not ask the less relevant question of whether a different firm lacking market power might undertake the same conduct and then seek to extrapolate from the answer to that hypothetical question. Such an inquiry could hardly be as informative as an evaluation of the dominant undertaking's actual conduct and likely or actual effects in an observable, as opposed to hypothetical, market.

Enforcement guidelines issued in 2012 by the CCB similarly focus on an analysis of the likely competitive impact of a dominant firm's conduct. Section 79(1) of Canada's Competition Act defines abuse of dominance as any anticompetitive act or practice that "has had, is having or is likely to have the effect of preventing or lessening competition substantially in a market". ${ }^{64}$ Reflecting this statutory directive that the offence be linked to adverse competitive effects, the CCB's 2012 Enforcement Guidelines on the abuse of dominance begin by emphasising that s 79(1) is concerned with conduct that "creates, preserves, or enhances market power". ${ }^{65}$ The Guidelines explain that "[i]n carrying out this assessment, the Bureau's general approach is to ask whether, but for the practice in question, there would likely be substantially greater competition in the market in the past, present, or future." 66 As is true for the EC, this "but for" approach focuses the inquiry on the effect of the conduct. To the extent there is any use of a "counterfactual", it is one rooted in the observed market. It compares the actual market with a market with the same firm and the same market conditions, but not the same conduct. The variable that is adjusted in the counterfactual, therefore, is the conduct, not the firm, which is held constant. In this way, the effect of the conduct is the focus of the inquiry. This starkly contrasts with the counterfactual as used in New Zealand, which holds the conduct constant, but treats the firm's power as a variable.

63 At [30] (emphasis added).

64 Competition Act RSC 1985 c C-34, s 79(1). See also Competition Bureau of Canada Enforcement Guidelines: The Abuse of Dominance Provisions (2012) at 1. For a discussion of the Act's abuse of dominance provisions that precedes the Guidelines, see Paul Crampton "'Abuse' of 'Dominance' in Canada: Building on the International Experience" (2006) 73 Antitrust LJ 803.

65 Competition Bureau of Canada, above n 64, at 13

66 At 12 . 
Similarly, the United Kingdom CMA's guidance on abuse of dominance states that the agency "would find an undertaking's behaviour an abuse only after detailed examination of the market concerned and the effects of the undertaking's conduct". ${ }^{67}$ In "assessing whether an undertaking is dominant", the first step in the analysis, the Guidelines focus on an assessment of the firm's market power. The discussion makes clear that the inquiry remains focused on the characteristics of the allegedly dominant firm and the market in which it operates. ${ }^{6}$ The Guidelines indicate that "the likely effect of a dominant undertaking's conduct on customers and on the process of competition is more important to the determination of an abuse than the specific form of the conduct in question". ${ }^{69}$ As in the EC and Canada, the relevant inquiry thus is concerned with the effects of the dominant firm's conduct, not inferences drawn from hypothetical, alternative firms or markets. And again, to the degree inferences are to be drawn from reliance on a counterfactual, the firm is held constant; the conduct is the variable.

\section{$B$ Testing the Counterfactual with Case Law from Other Jurisdictions ${ }^{70}$}

This section briefly examines several examples of conduct that have been the focus of litigation under the single-firm conduct prohibitions of various jurisdictions. The selected cases resulted in findings of liability, but the results might have been different had the conduct been judged under New Zealand's version of the counterfactual test. That should not come as a surprise. Much of the conduct considered shares a characteristic often found in close-call unilateral conduct cases: despite evidence of harm, a plausible argument could be made that at least under some circumstances the conduct could yield efficiencies. The counterfactual will perform especially poorly in such cases; that is, the error rate will be high when it is invoked to judge conduct that can be exclusionary under some circumstances, but can also yield efficiencies. This is so because it will tend to exonerate conduct based solely on the probability that the practice would be undertaken by a non-dominant firm, without taking into account the significance of the dominant firm's market power and its consequences for the conduct's effect on competition and the competitive process in the market as it actually exists. In other words, it will systematically produce false negatives precisely because it fails to take into account the characteristic that most drives jurisdictions to prohibit unilateral conduct: market power.

67 Office of Fair Trading, above n 55, at 3 (emphasis supplied). This guidance, issued by the Office of Fair Trading in 2004, has been adopted by the Board of the Competition and Markets Authority (CMA), which superseded the OFT in 2014

68 At $13-14$

69 At 18 (emphasis original).

70 The ICN has developed an extensive collection of reports, presentations and recommended practices regarding a variety of specific types of unilateral conduct. See <www.internationalcompetition network.org>. 


\section{Exclusionary distribution practices}

Exclusionary distribution practices can take a variety of forms, many of which are associated with plausible efficiency justifications. Across many jurisdictions, it is commonly recognised, for example, that practices such as exclusive dealing, various kinds of conditional pricing practices and tying can be procompetitive. ${ }^{71}$ Although there are some differences of opinion regarding the evidence that will warrant a prediction of actual or probable harm, there is also wide consensus that: (1) these kinds of practices can, when undertaken by a firm with market power, impede competition by raising rivals' costs and facilitating the exercise of market power; and (2) the mere fact that the practice can be efficient does not necessarily provide a reasonable basis for presuming that it is efficient in all circumstances.

As noted above, therefore, the EC Guidance observes that once anticompetitive harm is established, the dominant firm has the burden of demonstrating that its use of the practice resulted in efficiencies sufficient to eliminate the likely harm. That a firm without market power might undertake these distribution strategies will typically be relevant, but not outcome determinative. It may suggest the possibility of an efficient (or at least competitively neutral) use of the practice, but it does not establish that it will be beneficial in all instances when adopted by a firm with market power. That ultimate judgement is typically a question of fact to be determined in each case. ${ }^{72}$ Most importantly, across many jurisdictions, the critical inquiry will focus on the practice's actual or probable effects and the legal and economic standards used to evaluate them.

When these various kinds of distribution practices are implemented through agreements between sellers and buyers, they are often evaluated under competition law provisions related to concerted action. However, they have also and frequently arisen under single-firm conduct statutes because they can be unilaterally imposed without agreement. In such cases, the unilateral conduct prohibition will be the tool of choice - perhaps the only tool available - for evaluating their impact on competition. Several prominent examples from other jurisdictions illustrate this approach and demonstrate how the counterfactual will likely fail to function well as a tool for differentiating anti from procompetitive distribution-related practices.

71 The global literature on these practices is extensive and a review of it is beyond the scope of this article. For one survey on the law in the United States, see Andrew I Gavil "Exclusionary Distribution Strategies by Dominant Firms: Striking A Better Balance" (2004) 72 Antitrust LJ 3. See also Salop, Pozen and Seward, above $\mathrm{n}$ 57. One of the most hotly debated strategies has been conditional pricing practices, which include what have been labelled as "bundled rebates" or "loyalty" or "share" discounts. The United States Federal Trade Commission and Department of Justice held a workshop on these practices in June 2014. See "Conditional Pricing Practices: Economic Analysis and Legal Policy Implications" (23 June 2014) Federal Trade Commission <www.ftc.gov>.

72 See for example EC Guidance on Abuse of Dominance, above at 4, at [32]-[46] discussing various forms of exclusive dealing, and at [47]-[62] discussing tying. 
The Microsoft antitrust cases in Europe and the United States provide prominent and useful examples of how easily New Zealand's counterfactual could produce a false negative. ${ }^{73}$ Both jurisdictions challenged Microsoft's varied efforts to insulate its flagship Windows desktop computer operating system from new forms of competition. Whether characterised as exclusive dealing or tying, those efforts included Microsoft's "integration" strategy, what it described as adding new functionality to Windows. Whereas the United States case focused in part on Microsoft's integration of Internet Explorer (IE), an Internet browser, into Windows, the EC's initial case focused in part on its decision similarly to embed Windows Media Player in Windows. In both jurisdictions, the agencies and courts concluded that the integration strategy had the effect of insulating Windows from competition and that Microsoft had failed to support its integration strategy with evidence of technical or business justifications that might eliminate or otherwise justify those harms. ${ }^{74}$

How would these cases have been decided under New Zealand's counterfactual? If the sole relevant question was whether a non-dominant firm would have adopted an integration strategy, the cases might well have been decided in favour of Microsoft. The operating systems of non-dominant firms included Internet browsers and media players that were at least to some degree bundled, if not integrated. ${ }^{75}$ But those other firms did not possess Microsoft's market power. Hence, their use of an integration strategy posed no competitive threat - it could not have the same effect on competition as did Microsoft's. Moreover, Microsoft was required to go beyond hypothesising efficiencies or technical benefits for integration; it was expected to prove them - and it failed to do so. This is an evidentiary burden the counterfactual does not impose. As the United States Court of Appeals for the DC Circuit concluded: ${ }^{76}$

73 This assumes that one agrees with the outcomes in these two cases.

74 See United States v Microsoft Corp, above n 15; Case T-201/04 Microsoft Corp v Commission [2007] ECR II-3601. For a comprehensive account and analysis of the Microsoft antitrust cases, see Gavil and First, above n 29.

75 In the portion of its decision rejecting application of the United States "per se" rule against tying, the DC Circuit noted that integration was "common among firms without market power" and that "[t]he ubiquity of bundling in competitive platform software markets should give courts reason to pause before condemning such behaviour in less competitive markets": United States $v$ Microsoft Corp, above n 15, at 93. Nevertheless, in its analysis, at 64-67, of the Government's monopoly maintenance claim, this observation did not alter the Court's conclusion that Microsoft had failed to support any efficiency or technical justification for its integration strategy. See also Aspen Skiing Co v Aspen Highlands Skiing Corp, above $\mathrm{n}$ 14 , at 603 (defendant's continued cooperation with rivals in other geographic markets was deemed probative of its anticompetitive intent and of the effect of its conduct in the geographic market in which it refused to continue dealing with a rival after a long history of cooperation).

76 United States v Microsoft Corp, above n 15, at 66-67. The Court of First Instance (now the General Court) similarly concluded that Microsoft had failed to support its arguments that its integration strategy was somehow justified. See Microsoft Corp v Commission, above n 74, at [1091]-[1167]. 
Microsoft proffers no justification for two of the three challenged actions that it took in integrating IE into Windows - excluding IE from the Add/Remove Programs utility and commingling browser and operating system code. Although Microsoft does make some general claims regarding the benefits of integrating the browser and the operating system ... it neither specifies nor substantiates those claims. Nor does it argue that either excluding IE from the Add/Remove Programs utility or commingling code achieves any integrative benefit. Plaintiffs plainly made out a prima facie case of harm to competition in the operating system market by demonstrating that Microsoft's actions increased its browser usage share and thus protected its operating system monopoly from a middleware threat and, for its part, Microsoft failed to meet its burden of showing that its conduct serves a purpose other than protecting its operating system monopoly. Accordingly, we hold that Microsoft's exclusion of IE from the Add/Remove Programs utility and its commingling of browser and operating system code constitute exclusionary conduct, in violation of $\S 2$.

Precisely because the counterfactual fails to account for market power, and infers justifications based on the conduct of other, non-dominant firms, it will systematically err in cases such as Microsoft, where adverse competitive effects flow from the dominant firm's market power and conduct-specific efficiency evidence is lacking. ${ }^{77}$

\section{Refusals to deal and predatory pricing}

"Refusal to deal" with rival firms has been one of the most debated practices in competition policy. ${ }^{78}$ Sometimes involving vertically integrated monopolists and heavily regulated industries, refusals to deal present something of a paradox: in general, competition laws encourage rivalry, and specifically prohibit certain forms of firm-to-firm cooperation - "concerted action" that substantially reduces competition. A refusal to deal, therefore, would seem to be consistent with the promotion of rivalry, not an abuse of dominance. Many jurisdictions also hesitate to condemn refusals to deal owing to concerns about the wisdom and administrability of possible remedies. Imposing a duty to deal with a rival as a remedy for a refusal to deal would seem to be inconsistent with the overarching goal of promoting rivalry, and may require enforcers and courts to specify the terms of

77 For another recent example from the United States, see McWane Inc v Federal Trade Commission, above $\mathrm{n}$ 15, affirming the Federal Trade Commission's finding that a dominant firm engaged in anticompetitive exclusive dealing lacked any efficiency justification. See also ZF Meritor LLC v Eaton Corp 696 F 3d 254 (3d Cir 2012) where de facto exclusive dealing agreements were found to unreasonably foreclose competition; and United States $v$ Dentsply International Inc, above $\mathrm{n} 1$, reversing dismissal of the Government's challenge to the unilateral imposition of exclusive dealing by a dominant firm. The law of exclusion in the United States is demanding of plaintiffs, yet it is unlikely that any of these cases, each of which found liability, would have been decided the same way under s 36 as it is now being interpreted.

78 More broadly framed, the issue can be understood in remedial terms: when should competition law impose a duty to deal with a rival as a remedy for a competition law violation? Although the typical scenario involves a dominant firm's refusal to supply a rival and a request for mandated dealing, imposing a duty to deal could also be an appropriate remedy in cases involving other kinds of exclusionary conduct. And there may be alternative remedies to cases involving an unlawful refusal to deal, such as divestiture. 
dealing for some period of time. Nevertheless, most jurisdictions, albeit to differing degrees, have embraced the principle that a refusal to deal can under some circumstances be anticompetitive and hence constitute a form of monopolisation or abuse of dominance. ${ }^{79}$

Predatory pricing shares some common characteristics with refusal to deal. First, at least in its initial stage, the conduct would seem to be desirable: aggressive reductions in price will presumably benefit consumers. Secondly, it would seem anomalous for competition law enforcement agencies and courts to order firms to raise prices, but that is the almost inevitable result of a finding that prices have been set "too low". Finally, like a requirement that rivals deal with each other, ordering a firm to raise its prices might require continuing judicial or administrative oversight and difficult judgements about what the "competitive" price level ought to be at any given moment. Despite these concerns, and as with refusals to deal, most jurisdictions have endorsed the idea that in some cases prices should be condemned when "predatory". 80

In large part because of these somewhat distinctive and common characteristics, specific approaches and tests have been developed to evaluate refusals to deal and predatory pricing. Those approaches and tests all share a common goal, however: to identify refusals to deal and pricing practices that are likely to have anticompetitive effects. As with all single-firm conduct, but perhaps more so with these types of conduct, that is highly unlikely absent market power or a substantial threat that it can be acquired. Asking as the counterfactual does, therefore, whether a non-dominant firm would engage in the same conduct will be perhaps uniquely unrevealing of effects with respect to such conduct. It will also be uniquely difficult to construct the necessary hypotheticals.

New Zealand's leading decision on predatory pricing under s 36 is Carter Holt Harvey ${ }^{81}$ - and it is arguably subject to alternative interpretations. The Commerce Commission alleged that Carter Holt Harvey possessed substantial market power and that it responded to new entry by developing a competing product and then selling it below cost. In reviewing the decisions of the lower courts, the Privy Council appeared unequivocally to endorse reliance on the counterfactual for alleged

79 See for example Aspen Skiing Co v Aspen Highlands Skiing Corp, above n 14. Aspen Skiing Co must be read, however, in light of Verizon Communications Inc v Law Offices of Curtis V Trinko, above n 29, at 409, which maintained that the decision is "at or near the outer boundary of s 2 [Sherman Act] liability". The European courts have taken a more aggressive stance with respect to refusals to deal. See for example Microsoft Corp v Commission, above $\mathrm{n} 74$.

80 Most jurisdictions use an initial screen that compares price to cost and condemn only "below cost" pricing, although different measures of cost can be employed. There is a difference of viewpoint, however, as to whether proof of probable recoupment also should be required in addition to proof of below cost pricing. See generally International Competition Network Unilateral Practices Working Group Predatory Pricing Analysis Pursuant to Unilateral Conduct Laws: Recommended Practices (2014).

81 Carter Holt Harvey Building Products Group Ltd v Commerce Commission [2006] 1 NZLR 145 (PC). The decision cites to and relies upon Boral Besser Masonry Ltd $v$ Australian Competition and Consumer Commission [2003] HCA 5, (2003) 215 CLR 374. 
violations of s 36 , including predatory pricing. ${ }^{82}$ It immediately observed, however, that application of the counterfactual "requires particular care where, as in the present case, the impugned conduct consists of price cutting". ${ }^{83}$ To define that "particular care", it turned to Boral Besser and a wellknown decision from the United States, ${ }^{84}$ both of which had embraced the two-part test for predatory pricing followed in Australia, the United States and some other jurisdictions. As the Privy Council reasoned, "The margin between legitimate competition and anticompetitive conduct is not crossed by the lowering of prices. It is crossed when the dominant firm uses its ability to raise prices without losing its market share. 85 It later added: "A dominant firm uses its position of dominance when it engages in price cutting with a view to recouping its losses without loss of market share by raising prices without fear of reprisals afterwards. ${ }^{16} \mathrm{~A}$ violation of $\mathrm{s} 36$ for price cutting, therefore, would require proof of both pricing below some measure of cost and evidence of a probable later ability to recoup any losses incurred. These are indicia of probable anticompetitive effect.

Is this an application of the counterfactual or a rejection of it? To determine whether the prices charged by a dominant firm are below some measure of cost, the Commerce Commission and the courts will by necessity focus on the price and cost evidence gathered from that firm, not a hypothetical firm in a non-dominant position. Similarly, the inquiry into recoupment will focus on the dominant firm, its market power and the characteristics of the industry, not the hypothetical, non-dominant firm, which presumably and almost by definition would not be in a position either to price below cost or to recoup. The questions presented in a predatory pricing case, therefore, are not

82 Carter Holt Harvey Building Products Group Ltd v Commerce Commission, above n 81, at 164: "It follows that if a dominant firm is acting as a non-dominant firm otherwise in the same position would have acted in a market which was competitive it cannot be said to be using its dominance to achieve the purpose that is prohibited." It later reiterates, at 166, its commitment to the counterfactual in summarising the collective requirements of the previous cases: "It is ... both legitimate and necessary when giving effect to s 36 to apply the counterfactual test to determine whether the defendant has used its position of dominance."

83 At 164 .

84 Barry Wright Corp v ITT Grinnell Corp 724 F 2d 227 (1st Cir 1983) (the opinion was authored by Associate Justice Stephen Breyer of the United States Supreme Court when he was a Judge of the Court of Appeals). The two-step approach has been endorsed by the United States Supreme Court, as well. See Brooke Group Ltd v Brown \& Williamson Tobacco Corp 509 US 209 (1993) (pricing must be below some measure of cost and the defendant must have a probability of recouping the losses incurred during the period of below cost pricing); and Weyerhaeuser Co v Ross-Simmons Hardwood Lumber Co 549 US 312 (2007) (applying same standards to a monopsonist engaged in allegedly predatory bidding).

85 Carter Holt Harvey Building Products Group Ltd v Commerce Commission, above n 81, at 164 (emphasis in original).

86 At 166 
directed at the hypothetical firm in a competitive market, and cannot be answered with any precision by referring to it. ${ }^{87}$

This approach, with its more direct focus on the firm with substantial market power, its costs and its market position, is an arguable departure from the counterfactual as it has been described and applied in other cases. Carter Holt Harvey can be understood, therefore, not as a case that applied the counterfactual, but as one that implicitly recognised its limits as a guide to the application of $\mathrm{s}$ 36. Although one could argue that the Privy Council's approach supported the conclusion that a nondominant firm would not have priced below cost, and hence was an effective use of the counterfactual, that was not the question presented and would be something of a reverse application of the test. At most, it is possible to view the Privy Council's approach as a specialised application of the counterfactual, but it surely seems to have been prompted by an awareness that rigid application of the counterfactual would lead to unacceptable results. The remaining question is whether the "particular care" that justified departure in a predatory pricing case is warranted in other cases under s 36 , as well.

Similarly, although the incentives of large and small firms in responding to a request to deal might be very different, in some cases they might be the same: both would refuse to share their products, services or know-how with a rival. But that refusal is wholly unlikely to have any competitive significance if undertaken by a firm lacking market power. The counterfactual, therefore, might systematically lead to false negatives, precisely because it does not look at the different effects that can flow from a refusal to deal by a firm with and without market power. It might yield the correct outcome in some cases, but not necessarily for the right reasons.

Again, the European Microsoft case is informative. ${ }^{88}$ One of the central allegations in the EC's case against Microsoft was that it had refused to share sufficient information about its desktop

87 For the Commerce Commission's explanation of the case, which confirms this approach, see Commerce Commission Case study: Predatory pricing or competitive price matching? (June 2012). Even if it had intended to apply the counterfactual, the Privy Council could not have done so in any sensible way. It would first have asked whether a non-dominant firm would have priced below cost under the same circumstances. But would the calculation be based on the hypothetical competitive firm's costs or those of the dominant firm, which might benefit from economies of scale? The "other circumstances" are difficult to hold constant. Even if that question could be resolved, the results of the inquiry would necessarily be ambiguous. The answer might be "no", the non-dominant firm would not price below cost, but that might be either because it lacks the means to finance a below cost strategy or because it lacks the incentive to do so because it could not recoup any losses suffered. In either event, could it then safely be inferred that the dominant firm must have been taking advantage of its substantial market power? That a non-dominant firm cannot recoup losses does not necessarily support the inference that a dominant firm can. Such an approach would likely result in a false positives and over-deter aggressive pricing. It would be prudent, therefore, as the Privy Council held, to undertake an independent evaluation of the dominant firm's ability to recoup. The questions themselves do not seem to be informative and hence were not posed.

88 Microsoft Corp v Commission, above n 74. 
operating system, Windows, to allow for smooth interoperation between computers running Windows and Sun Microsystems' server operating systems. Microsoft argued that the necessary information was proprietary and that sharing it would undermine innovation incentives for both itself and Sun. Both the Commission and the Court of First Instance rejected Microsoft's arguments, concluding that its refusal to share the necessary interoperability information had an anticompetitive effect and could not be justified. ${ }^{89}$

How would the analysis have proceeded in New Zealand under the counterfactual? If a nondominant firm would similarly have refused to deal, perhaps in order to protect its know-how, the counterfactual would have inferred that, in doing so, Microsoft was not acting with the purpose of taking advantage of its market power. Exonerating Microsoft, however, would entirely ignore the reality that a refusal to deal by a firm lacking market power is unlikely ever to have any appreciable impact on competition - not true for a firm with substantial and durable market power. It thus sidesteps the more salient questions of whether Microsoft's refusal to deal had any significant impact on competition and whether it had any justification for its conduct. Even critics of the EC's and Court of First Instance's conclusion that Microsoft's refusal to deal with Sun constituted an infringement of art 102 would likely agree that these are the right questions to be addressed. Conversely, what if the non-dominant firm would have happily shared its interoperability information in order to expand use of its operating system and maximise its profits? Would it then have been warranted to infer that Microsoft's refusal to deal necessarily involved "taking advantage of" its market power? Such a conclusion might be warranted, and in this instance the counterfactual could reach a correct conclusion. It might rightly infer that the dominant firm was refusing to deal in order to impede its rivals and perpetuate its monopoly. On the other hand, the dominant firm might have had competitively neutral justifications and considerations for doing that which was simply unavailable to the non-dominant firm - justifications that would go unconsidered under the counterfactual.

To be sure, in most jurisdictions cases challenging refusals to deal must be carefully considered and will likely be rare. The counterfactual approach to assessing refusals to deal might provide an accurate prediction in some cases, but almost by accident and randomly. For a non-dominant firm, agreeing to deal with rival firms, especially larger ones, could be entirely sensible. It could open it up to a much larger market and allow it to reach economies of scale otherwise unreachable. But for the dominant firm that has already reached scale, the risks to sharing might make refusing to deal a

89 For a discussion of this aspect of the case, see Gavil and First, above n 29, at 203-210 and 218-222. See also EC Guidance on Abuse of Dominance, above at 4, at [75]-[90]. For an analysis of refusals to deal by an unregulated, vertically integrated monopolist, see Steven C Salop "Refusals to Deal and Price Squeezes by an Unregulated, Vertically Integrated Monopolist" (2010) 76 Antitrust LJ 709. For another that focuses on intellectual property, see Howard A Shelanski "Unilateral Refusals to Deal in Intellectual and Other Property" (2009) 76 Antitrust LJ 369. 
rational strategy. ${ }^{90}$ What is clear is that the effects of a dominant firm's refusal to deal are likely to be so different when compared to a refusal by a non-dominant firm as to make reliance on the counterfactual unlikely to yield any reliable inferences.

\section{CONCLUSION}

The principal justification for retaining the counterfactual test is to constrain the scope of $\mathrm{s} 36$. It is a permissive test that will provide firms with substantial market power a wide berth to pursue aggressive competitive strategies, leaving little room for successful challenges to their conduct. As I have argued, however, there should be no pretence that it will achieve this goal because it accurately differentiates competitive from exclusionary conduct. To the contrary, it will do so by default, often misdiagnosing the competitive desirability of conduct because it fails to consider its market effects. If it is certain and predictable, it is because it imposes burdens that will rarely be met. Several paths to reform might therefore be pursued.

First, despite the New Zealand Supreme Court's seeming commitment to the counterfactual in 0867, the Commission might consider initiating another, more stark test case; one that would likely "pass" the counterfactual test, but present the courts with an uncomfortably obvious instance of anticompetitive effects. Instances of such "naked exclusion" will likely be rare, but such a case might provoke greater receptivity to alternative interpretations of the current language. The question is, if confronted with an obviously anomalous result, would the courts bend? The treatment of predatory pricing offers some hope for flexibility.

The alternative, as is well known, is amendment. Some minor improvements could be attempted, such as the addition of an effects test, such as that in s 27 , which would explicitly require consideration of pro and anticompetitive effects. A likely argument against such an approach would be its greater complexity, cost and uncertainty. But as I have argued, the counterfactual does not necessarily alleviate those concerns. A revised statute might address them by building in guided presumptions that would more easily shift burdens, so that easier cases might be more quickly decided. The intermediate approach of specifying presumptions might also serve to deter more obviously anticompetitive conduct, while creating safe harbours for conduct more likely to be procompetitive.

90 The High Court of Australia seemed to take a more effects-focused approach to its analysis of a refusal to supply in Queensland Wire Industries Pty Ltd v The Broken Hill Pty Ltd, above n 13. Although there are reflections of a counterfactual analysis, it is one that was informed by evidence that specifically related to the defendant. The Court observed, for example, at [28], that if the defendant "were operating in a competitive market - it is highly unlikely that it would stand by, without any effort to compete, and allow the appellant to secure its supply ... from a competitor". It further observed, at [29], that the defendant sold the same product in markets where it faced competition, and that it "did not offer a legitimate reason for the effective refusal to sell". These observations are not based on inferences drawn from a hypothetical competitive market, but from evidence relating to the defendant and its actual conduct in the market examined. 
Finally, there is the possibility of major reform. With Australia now appearing to take the lead, conditions might be ripe for substantial reconsideration of $\mathrm{s} 36$. The rationale for the counterfactual, as I have argued, is highly questionable. It will be prone to error in many common circumstances, is inconsistent with other provisions of the Commerce Act, and is clearly out of step with developing global norms. It is likely providing encouragement to dominant firms to respond aggressively to competitive challenges, and not necessarily on the merits, to the detriment of New Zealand's consumers and perhaps to its global competitiveness. It may also be stifling development of a more sophisticated body of economically informed law concerning exclusionary conduct by firms with market power. Consideration of a "counterfactual" approach to rebalance New Zealand's approach to single-firm conduct would appear to be in order. 